University of Massachusetts Amherst

ScholarWorks@UMass Amherst

Chemistry Department Faculty Publication Series

Chemistry

2001

\title{
Microwave-assisted extraction of monomethyl arsonic acid from soil and sediment standard reference materials
}

PM Yehl

H Gurleyuk

JF Tyson

PC Uden

Follow this and additional works at: https://scholarworks.umass.edu/chem_faculty_pubs

Part of the Chemistry Commons

\section{Recommended Citation}

Yehl, PM; Gurleyuk, H; Tyson, JF; and Uden, PC, "Microwave-assisted extraction of monomethyl arsonic acid from soil and sediment standard reference materials" (2001). Analyst. 1037.

Retrieved from https://scholarworks.umass.edu/chem_faculty_pubs/1037 


\title{
Microwave-assisted extraction of monomethyl arsonic acid from soil and sediment standard reference materials
}

\author{
Peter M. Yehl, † Hakan Gurleyuk, + Julian F. Tyson* and Peter C. Uden \\ Department of Chemistry, University of Massachusetts, 701 Lederle Graduate Research \\ Tower, 710 North Pleasant St., Amherst, MA 01003-9306, USA. \\ E-mail:Tyson@chem.umass.edu
}

Received 20th March 2001, Accepted 22nd June 2001

First published as an Advance Article on the web 20th August 2001

\begin{abstract}
Arsenic-containing species were extracted from soil and sediment SRM by a mixture $(1+1)$ of acetone and hydrochloric acid (10\% v/v) in a sealed vessel in a microwave oven during heating to $160{ }^{\circ} \mathrm{C}$ at pressures up to $1150 \mathrm{kPa}$ (160 psi). Following separation by anion-exchange HPLC those species which gave a volatile derivative on reaction with borohydride in acid were detected by plasma-source mass spectrometry. The procedure was used to determine the monomethyl arsonate species in SRM 2704 Buffalo River sediment (0.30 ppm), SRM 1944 New York-New Jersey waterway sediment (0.23 ppm) and in SRM 2710 highly elevated Montana soil (1.03 ppm). The method was developed by investigating the recovery of dimethylarsinate added to Buffalo River sediment as a function of various experimental parameters, including the composition of the solvent. For $1+1$ mixtures of acetone and $5 \% \mathrm{HCl}$, methanol and $5 \% \mathrm{HCl}$, and isopropanol and $5 \% \mathrm{HCl}$, recoveries ranged from $91 \%$ to $112 \%$. Similar recoveries were obtained for ultrasound-assisted extractions with the same solvents. The chromatographic eluent was not directly introduced into the mass spectrometer as, compared to the post-column hydride generation procedure, the sensitivity was too low for reliable quantitative measurements, although the chromatographic resolution was better. Problems with signal pulsations were overcome by incorporating pulse dampers into the reagent delivery lines.
\end{abstract}

\section{Introduction}

Biological methylation of arsenic in fungal cultures has been understood for many years. ${ }^{1}$ Methylation of arsenic by bacteria is known to occur through a metabolic reaction which uses methylcobalamin (the methyl transfer compound) and adenosine triphosphate (the energy source) in controlled anaerobic climates, ${ }^{2}$ and in lake sediments. ${ }^{3}$ The rate of production of monomethyl arsonic acid by arsenic-tolerant anaerobic bacteria has been studied. 4

Naturally existing methylated arsenic species are probably the result of a biological transformation of inorganic arsenic. Biological methylation of antimony in a soil medium, ${ }^{5}$ and of selenium, ${ }^{6}$ tin, ${ }^{7}$ tellurium, ${ }^{8}$ mercury, ${ }^{9}$ and lead, ${ }^{10,11}$ predominantly in anaerobic cultures, have been demonstrated. It has been shown that antimony is reduced prior to methylation. ${ }^{5}$ It can be speculated that methylated forms of arsenic exist in nature, and are probably the result of biological transformation, ${ }^{12}$ but to date very few studies have found methylated arsenic in either soils or sediments. A recent study has shown that biological conversion of arsenic to various methylated forms takes place by the fungus Laccaria amethystina or its associated bacteria in a largely anaerobic environment. ${ }^{13}$ This work demonstrated that such a conversion is not restricted to marine biota.

$\dagger$ Present address: Merck Research Laboratories, P.O. Box 2000, Building RY-818-B215, Rahway, NJ 07065, USA.

\$ Present address: Frontier Geosciences Inc., 414 Pontius Avenue N., Seattle, WA 98109, USA.
Arsenic speciation in nature is important from a number of perspectives. Different forms of arsenic have vastly different toxicity to humans due to human bioavailability. For example, inorganic arsenic [As(III) and As(v)] are carcinogenic, and can cause neurological, cardiovascular, and hematological disorders, ${ }^{14}$ while monomethyl arsonic acid (MMA) is believed to be far less toxic. ${ }^{15}$ The long-term effects of dimethyl arsinic acid (DMA) are not fully understood. ${ }^{16}$ Still other forms (arsenobetaine, arsenocholine) have been deemed essentially inert, and are excreted readily by humans with little or no absorption. ${ }^{17}$ Arsenic compounds such as arsenic metal oxides and arseno-phosphates that are not readily water soluble have been shown to be less toxic than water soluble compounds because they are less bioavailable. ${ }^{18,19}$

The chemical speciation of arsenic affects its environmental mobility. Inorganic As(v) is relatively sedentary in soil, and can be adsorbed onto clays or precipitated with sulfur, iron and aluminum. ${ }^{20}$ Methylated As(v) is less likely to precipitate and therefore is mobilized when it comes into contact with water. Although As(III) can be volatilized more readily than As(v), and there is a wide range in the degree of volatility between methylated As(III) species.

Elemental speciation in a soil matrix requires the extraction and separation of the species without changing the chemical form. For the trace concentration speciation of arsenic, the separation must be coupled with a detection technique having low detection limits, such as ICP-MS, ICP-OES or AAS, capable of monitoring transient chromatographic signals. The recent literature contains many papers describing arsenic speciation in a number of matrices. Some of the procedures that were first employed to quantify arsenic species are given in Table 1. 
Arsenic extraction and speciation have been attempted for a number of matrices including urine, $23,34,41$ marine biological tissues, ${ }^{23,35,40,42-55}$ mushrooms, ${ }^{12}$ and soils, ${ }^{28-31,56,57}$ but to date there has been no work in which individual methylated arsenic species in soil or sediment SRM were quantified. Analytical methodology for the extraction, recovery and determination of arsenic species has been reviewed. ${ }^{58}$ Examples of the extraction of organometallic compounds from various environmental matrices are given in Table 2. Methylated arsenic forms were not detected in water extracts. ${ }^{30}$ The use of a solvent capable of ion-exchange or forming an ion-pair may be desirable when extracting ionic species such as MMA or DMA, particularly from matrices with ionic binding sites. ${ }^{32,57}$

Table 1 Arsenic separation and determination techniques

\begin{tabular}{|c|c|c|c|c|}
\hline Reference & Matrix & Separation technique & Detection & Species determined ${ }^{a}$ \\
\hline 21 & DI water & HPLC(IC) & ICP-MS/Flame AAS & As(III), As(v), MMA, DMA, AsB \\
\hline 22 & DI water & HPLC(IC) & Flame AAS & $\mathrm{As}(\mathrm{v}), \mathrm{TMA}, \mathrm{AsC}$ \\
\hline 23 & Urine, Marine org & HPLC(IC) & Flame AFS & As(v), MMA, DMA \\
\hline 24 & DI water & HPLC(IC) & ICP-MS & As(III), As(v), MMA, DMA \\
\hline 25 & DI water & & HG-ETA & $\operatorname{As}(\mathrm{III}), \operatorname{As}(\mathrm{v})$ \\
\hline 26 & River sediment & HPLC(IC) & HG-ETA & $\operatorname{As}(\mathrm{III}), \operatorname{As}(\mathrm{v}), \mathrm{MMA}$ \\
\hline 27 & & HPLC(IC) & GFAAS/thermospray MS & As(III), As(v), MMA, DMA, AsB, AsC \\
\hline 28,29 & DI water & HPLC (IC) & MO-HG-ICP-MS & $\operatorname{As}(\mathrm{III}), \operatorname{As}(\mathrm{v}), \mathrm{MMA}, \mathrm{DMA}$ \\
\hline 30 & Soil & HPLC(IC) & HG-FAAS & $\mathrm{As}(\mathrm{v})$ \\
\hline 31 & Soil & HPLC(IC) & GFAAS & As(v), MMA, DMA \\
\hline 32 & Soil & HPLC(IC) & DC-AES & As(III), As(v), DMA, MMA \\
\hline 33 & Soil & HPLC(IC) & HG-AAS & $\mathrm{As}(\mathrm{III}), \mathrm{As}(\mathrm{v})$ \\
\hline 34 & Urine & HPLC(IC) & UV-HG-AAS & As(III), As(v), MMA, DMA, TMAO, TMA, AsB, AsC \\
\hline 35 & Marine organisms & HPLC(IC) & ICP-OES, HG-AAS & MMA, DMA, AsB, AsC \\
\hline 36 & Flyash & HPLC(IC) & ICP-MS & As(III), As(v), MMA, DMA \\
\hline 37 & Urine & HPLC(IC) & ICP-MS & As(v), DMA, arsenosugar metabolites \\
\hline 38 & DI water & HPLC(IC) & HG-ICP-AES & As(III), As(v), MMA, DMA \\
\hline 39 & DI water & GC-cryotrap & HG-ETA & MMA \\
\hline 40 & Seaweed & GC & GFAAS, AAS & As(III), As(v), MMA, DMA \\
\hline 41 & Solvent & GC & MIP-AES & TMAO \\
\hline 42 & $\begin{array}{l}\text { Marine organism } \\
\text { tissues }\end{array}$ & HPLC & ICP-MS & DMA, TMA, AsB, As containing ribofuranosides \\
\hline
\end{tabular}

a $\mathrm{As}(\mathrm{III})$ : inorganic arsenite, $\mathrm{AsO}_{3}{ }^{2-}$; $\mathrm{As}(\mathrm{v})$ : inorganic arsenate $\mathrm{AsO}_{4}{ }^{3-} ; \mathrm{MMA}$ : monomethyl arsonate, $\mathrm{CH}_{3} \mathrm{AsO}_{3}{ }^{2-} ; \mathrm{DMA}^{-}$dimethyl arsinate, $\left(\mathrm{CH}_{3}\right)_{2} \mathrm{AsO}{ }_{2}^{-}$; TMAO: trimethyl arsenic oxide, $\left(\mathrm{CH}_{3}\right)_{3} \mathrm{AsO}$; TMA: tetramethyl arsonium, $\left(\mathrm{CH}_{3}\right)_{4} \mathrm{As}^{+}$; AsB: arsenobetaine, $\left(\mathrm{CH}_{3}\right)_{3} \mathrm{As}^{+} \mathrm{CH}_{2} \mathrm{COO}^{-}$; $\mathrm{AsC}$ : arsenocholine, $\left(\mathrm{CH}_{3}\right)_{3} \mathrm{As}^{+} \mathrm{CH}_{2} \mathrm{CH}_{2} \mathrm{OH}$.

Table 2 Extraction techniques for organometallic compounds

\begin{tabular}{|c|c|c|c|c|}
\hline Reference & Metallic species extracted & Matrix & Instrumentation and procedures & Extraction solvent \\
\hline 59 & General organometallic & Fine sediment & Soaking, sonication & $\mathrm{HCl}(\mathrm{aq})$ then ethyl acetate \\
\hline 60 & Organotin compounds & Fine sediment & Sonication & $\mathrm{HCl}$ then diethyl ether \\
\hline 61 & Organotin compounds & Fine sediment & Sonication and centrifugation & 1-butanol \\
\hline 62 & Organotin compounds & $\begin{array}{l}\text { Biological samples and } \\
\text { sediment }\end{array}$ & Centrifugation, separatory funnel & $\begin{array}{l}\text { Hexane or ethyl acetate or both after } \\
\mathrm{HCl}, \mathrm{NaCl} \text { and } \mathrm{H}_{2} \mathrm{O}\end{array}$ \\
\hline 47,51 & Organoarsenicals & Marine animal tissue & Microwave assisted extraction & $\mathrm{MeOH}-\mathrm{H}_{2} \mathrm{O}$ \\
\hline 52 & Organoarsenicals & Marine animal SRM & Accelerated solvent extraction & \\
\hline 56 & Arsenicals & Soil & Sequential extraction & $\mathrm{HCl}$, chloroform \\
\hline 57 & Arsenicals & Soil, sediments & Microwave extraction & Phosphoric acid \\
\hline 53 & Organoarsenicals & Shellfish & Sonication & $\mathrm{MeOH}$ and phosphate buffer \\
\hline 54 & Organoarsenicals & Shellfish & Heat $\left(85^{\circ} \mathrm{C}, 3 \mathrm{~h}\right)$ & Chloroform-MeOH; then water \\
\hline 42 & Organoarsenicals & Shellfish tissue & Sonication and centrifugation & $\mathrm{MeOH}-\mathrm{H}_{2} \mathrm{O} 1: 1$ \\
\hline 28 & Arsenicals & Soil & Sonication at $45^{\circ} \mathrm{C}$ & Water \\
\hline 55 & General organometallic compounds & Fine sediments & Sonication & $\mathrm{HCl}-\mathrm{MeOH}$ and benzene \\
\hline 55 & General organometallic compounds & Soils and sediments & Soxhlet apparatus & Acetic acid-toluene \\
\hline $63-65$ & $\begin{array}{l}\text { Metalloporphyrins; diketonates, and } \\
\text { dithiocarbamate and labile } \\
\text { organometallic compound }\end{array}$ & Soils and sediments & SFE & Supercritical $\mathrm{CO}_{2}$ \\
\hline 66 & Organotin compounds & Soil and sediment & SFE & Supercritical $\mathrm{CO}_{2}$ \\
\hline $67-69$ & Polyvalent inorganic metal ions & $\begin{array}{l}\text { Soils and sediments of } \\
\text { different organic contents }\end{array}$ & Centrifugation and agitation & Sequential inorganic solvents \\
\hline 70 & Polyvalent inorganic metal ions & Soils & N/A & DTPA and EDTA \\
\hline 71 & Polyvalent inorganic metal ions & Soil; soil surface & N/A & Ammonium acetate \\
\hline 72,73 & Organic and inorganic ions & Soil & $\begin{array}{l}\text { Pretreatment with } \\
\text { mercaptoethanol; Soxhlet } \\
\text { apparatus }\end{array}$ & $\begin{array}{l}\text { Sequential extractions with acids } \\
\text { then increasingly polar organic } \\
\text { acids }\end{array}$ \\
\hline 74 & General organometallic & Reference materials & Review & $\begin{array}{l}\text { Various strategies and } \\
\text { considerations }\end{array}$ \\
\hline
\end{tabular}


Compared to pressurized solvent extraction, Soxhlet extraction or sonication, microwave assisted extraction (MAE) differs in that heating takes place internally rather than by convection. Perhaps more importantly, in a sealed vessel the system becomes pressurized when the sample-solvent system absorbs microwave radiation. In this enclosed system, higher temperatures can be achieved, having the effect of accelerating the desorption of the analyte into the extraction solvent. The higher pressures improve the solvent-matrix interaction and hence improve the extraction efficiency. The technique is quicker and more versatile than many traditional extraction techniques. For example, a methanol extraction and a nitric acid digestion can be performed in two vessels simultaneously within the same run. Alternatively, different extractions can be performed simultaneously which target different classes of analytes.

MAE has gained acceptance as a means of extracting organic pesticides and pollutants, ${ }^{75,76}$ and has been used to remove organophosphorus compounds from lake sediment, ${ }^{77}$ and organoarsenic compounds from marine life, ${ }^{51}$ soils, and sediments ${ }^{57}$ with some success.

A problem for method development in the area of trace speciation of organometallic compounds in environmental samples is that there are very few reference materials available to help with method validation. Currently there are no soil and sediment materials available for which the arsenic species content has been certified, though there are several such materials for which the total arsenic content is certified. One possible approach to the production of speciated reference materials is to determine the required species in existing SRM. We have shown ${ }^{81}$ that NIST SRM 2704 (Buffalo River sediment) contains a measurable amount of DMA (extracted with the help of ultrasound by methanolic $\mathrm{HCl}$, separated from other As-containing species by anion-exchange HPLC and measured by directly coupled ICP-MS). We have now extended this work by the development of an MAE procedure, and improved the detection capability of the chromatographic system by incorporating post-column hydride generation. Recovery and possible degradation were investigated for DMA added to SRM 2704 (which does not contain a detectable amount of DMA) and the procedure developed applied to the determination of MMA in three NIST SRM (2704, Buffalo River sediment; 1944, New York-New Jersey waterway sediment; and 2710, Montana soil with highly elevated traces)

\section{Experimental}

\section{Instrumentation}

Sonication extraction experiments were performed in $50 \mathrm{ml}$ Erlenmeyer flasks sealed with Parafilm in a 11 ultrasonic bath (E/MC RAI, model 450). A microwave extraction unit (Questron Q-max 4000, Mercerville, NJ) equipped with a laptop NEC286 personal computer was used for all MAE experiments. The unit's software was capable of monitoring pressure within a control vessel and controlling temperature by adjusting the microwave power output. All vessels were Teflon-lined high pressure vessels fitted with high pressure rupture disks. Pressure and temperature were calibrated using the manufacturer's protocols.

For HPLC, the column used was a Hamilton (Reno, NV) PRP-X100 anion-exchange column $(150 \mathrm{~mm} \times 4.1 \mathrm{~mm}$ id; 10 $\mu \mathrm{m}$ particle size). Mobile phase was delivered isocratically by a Waters 6000-A dual piston pump at a flow of $2.0 \mathrm{ml} \mathrm{min}^{-1}$. The injection volume (manual Rheodyne six-port valve) was 20 $\mu 1$.
The post-column derivatization manifold is shown in Fig. 1. A peristaltic pump (Ismatec) was used in the hydride generation manifold. All reaction manifold tubing and fittings were Teflon $(0.5 \mathrm{~mm}$ id $)$. The pulse dampers shown were made by connecting a $20 \mathrm{~cm}$ length of $0.5 \mathrm{~mm}$ plugged Teflon tubing to a tee-joint connection after the Tygon peristaltic pump tubing. The optimized reaction coil lengths and reagent flow rates are shown in Table 3. A glass bead gas-liquid separator was used prior to introduction into the mass spectrometer. Argon was supplied to the manifold and to the mass spectrometer through

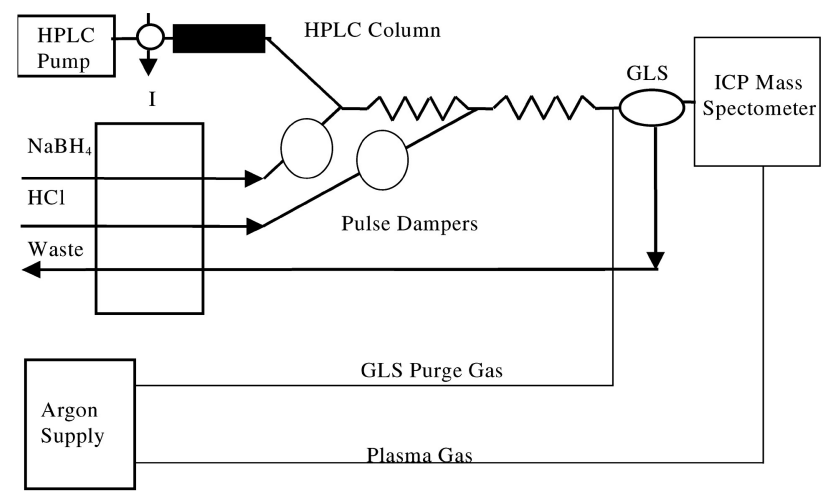

Fig. 1 Arsenic speciation manifold. Following separation, arsenic species are introduced to a hydride generation manifold. The arsine vapors generated in the reactor coil are then separated from the liquid in the gasliquid separator (GLS) prior to introduction to the inductively coupled plasma mass spectrometer.

Table 3 Instrumentation parameters

\begin{tabular}{|c|c|}
\hline \multicolumn{2}{|l|}{ A. Hydride generation } \\
\hline $\begin{array}{l}\text { Reaction coil length } \\
(0.5 \mathrm{~mm} \text { dia })\end{array}$ & $1.5 \mathrm{~m}$ \\
\hline Gas-liquid separator & glass bead \\
\hline $\begin{array}{l}\text { Hydrochloric acid } \\
\text { concentration }\end{array}$ & $25 \%(\mathrm{v} / \mathrm{v})$ \\
\hline $\mathrm{HCl}$ flow rate & $7 \mathrm{ml} \mathrm{min}^{-1}$ \\
\hline $\mathrm{NaBH}_{4}$ concentration & $1.5 \%(\mathrm{~m} / \mathrm{v})$ \\
\hline $\mathrm{NaBH}_{4}$ flow rate & $4 \mathrm{ml} \mathrm{min}-1$ \\
\hline Waste flow rate & $20 \mathrm{ml} \mathrm{min}^{-1}$ \\
\hline Purge gas flow rate & $0.9001 \mathrm{~min}^{-1}$ \\
\hline \multicolumn{2}{|l|}{ B. $H P L C$} \\
\hline Column & $\begin{array}{l}\text { Hamilton PRP X-100, } 10 \mu \mathrm{m} \text { anion- } \\
\quad \text { exchange column, } 150 \mathrm{~mm} \times 4.1 \mathrm{~mm}\end{array}$ \\
\hline Injection volume & $20 \mu \mathrm{l}$ \\
\hline Flow rate & $2.0 \mathrm{ml} \mathrm{min}^{-1}$ \\
\hline Mobile phase & $10 \mathrm{mM} \mathrm{PO}_{4}{ }^{3-}, \mathrm{pH} 6.0$, isocratic \\
\hline \multicolumn{2}{|l|}{ C. Mass spectrometer } \\
\hline Coolant gas flow & $15.01 \mathrm{~min}^{-1}$ \\
\hline Auxiliary gas flow & $1.01 \mathrm{~min}^{-1}$ \\
\hline Purge gas flow & $0.8-1.01 \mathrm{~min}^{-1}$ \\
\hline Mass/charge monitored & 75 \\
\hline Collection frequency & $8 \mathrm{~Hz}$ \\
\hline Dwell time & $0.125 \mathrm{~s}$ \\
\hline Data collection mode & continuous \\
\hline \multicolumn{2}{|c|}{ D. Microwave extraction program } \\
\hline Maximum pressure & $1150 \mathrm{kPa}$ \\
\hline Maximum temperature & $160^{\circ} \mathrm{C}$ \\
\hline Power & $1000 \mathrm{~W}$ \\
\hline Start ramping time & $0 \mathrm{~min}$ \\
\hline Starting temperature & $25^{\circ} \mathrm{C}$ \\
\hline End ramping time & $6 \mathrm{~min}$ \\
\hline Ending temperature & $155^{\circ} \mathrm{C}$ \\
\hline $\begin{array}{l}\text { Time held at final } \\
\text { temperature }\end{array}$ & $15 \mathrm{~min}$ \\
\hline
\end{tabular}


mass flow controllers. The dampers, inserted into the flow lines prior to the reaction confluence point, stabilized reagent deliveries improving the $\mathrm{S} / \mathrm{N}$, and preventing the plasma from being extinguished due to fluctuation in the hydrogen flow.

A PerkinElmer Sciex ELAN-5000 plasma source mass spectrometer, equipped with a laboratory-built Teflon hydride adapter, was used as the detector. The spectrometer settings are shown in Table 3 . The spectrometer was controlled with an IBM 386DX computer and PerkinElmer ELAN software.

\section{Chemicals and reagents}

Stock solutions of $100 \mu \mathrm{g} \mathrm{ml}^{-1}$ arsenic as MMA, DMA, As(III) and $\operatorname{As}(\mathrm{v})$ were made and diluted to appropriate volume with deionized water (DI; E-pure, $18.0 \mathrm{M} \Omega \mathrm{cm}^{-3}$ ) before analysis. Standard solutions of $100 \mu \mathrm{g} \mathrm{ml}^{-1}$ arsenic as MMA $(0.2506 \mathrm{~g}$ of $\mathrm{CH}_{3} \mathrm{AsO}_{3} \mathrm{Na}_{2}$, ChemSource, 98\%), arsenic as DMA (0.2915 g of $\mathrm{C}_{2} \mathrm{H}_{6} \mathrm{AsNaO}_{2} \cdot 3 \mathrm{H}_{2} \mathrm{O}$, Fluka, 98\%), arsenic as inorganic As(III) (0.1737 $\mathrm{g}$ of NaAsO2, Mallincroft, analytical grade assumed $100 \%)$ and arsenic as $\mathrm{As}(\mathrm{v})(0.4164 \mathrm{~g}$ of $\mathrm{Na}_{2} \mathrm{HAsO}_{4} .7 \mathrm{H} 2 \mathrm{O}$, Fisher, assumed $100 \%$ ) were prepared in $1000 \mathrm{ml}$ calibrated flasks. The $\mathrm{HCl}$ used was Fisher certified ACS plus grade, and the reductant used was NaBH4 (Alfa Aesar, granulated, $98 \%$ purity).

Extraction solvents for the MAE and sonication were prepared by mixing equal volumes of $10 \%(\mathrm{v} / \mathrm{v}) \mathrm{HCl}$ and the pure solvent to give solutions containing $5 \%(\mathrm{v} / \mathrm{v}) \mathrm{HCl}$ and $50 \%$ $(\mathrm{v} / \mathrm{v})$ organic modifier (on an volume/volume basis) in deionized water (E-pure, Millipore). The organic modifiers were Fisher HPLC-grade acetone, methanol, or isopropanol.

The chromatography mobile phase was $10 \mathrm{mM}$ ammonium dihydrogen phosphate (BDH AnalaR Grade), adjusted to $\mathrm{pH} 6.0$ with $0.1 \% \mathrm{NH}_{4} \mathrm{OH}$ (Fisher certified ACS grade).

\section{Extraction}

To evaluate the extraction efficiency, $0.5 \mathrm{~g}$ samples of SRM 2704 were weighed into either $25 \mathrm{ml}$ Erlenmeyer flasks (for sonication), or PTFE lined vessels (for MAE). The samples were spiked with $200 \mu \mathrm{l}$ of $100 \mu \mathrm{g} \mathrm{ml}^{-1}$ DMA stock solution. Deionized water $(1.0 \mathrm{ml})$ was then added to the spiked sediments, and the contents were mixed with a polyethylene spatula to ensure homogeneity of the DMA. The samples were dried in an oven at $50^{\circ} \mathrm{C}$ for $12 \mathrm{~h}$ and allowed to equilibrate for $6 \mathrm{~d}$. After equilibration, approximately $10 \mathrm{ml}$ of the extraction solvent was added to the vessels and flasks. For the sonication extraction, samples were sonicated for $2.0 \mathrm{~h}$. For MAE, the extraction program shown in Table 3 was run.

\section{Method validation and optimization}

The HPLC conditions were selected on the basis of previous work. The Hamilton PRP-X100 column, a strong quaternary amine anion-exchanger, has been used in the separation of arsenic compounds by other investigators. ${ }^{78-80}$ Kaise and coworkers have shown that a suitable mobile phase for the separation of arsenicals is phosphate at a $\mathrm{pH}$ of $6.0 .{ }^{44-46}$

In our preliminary investigations of arsenic species in NIST SRM 2704, the column eluent was directly aspirated. ${ }^{81}$ Although this procedure was reproducible and gave good improved resolution it suffered from poor sensitivity and degraded the nickel sampler and skimmer cones of the mass spectrometer. On-line hydride generation of the column eluent eliminated these practical shortcomings. The manifold was optimized (also using the multicycle univariate method) so as to maximize the sensitivity of MMA and DMA peaks following chromatographic separation. The reaction coil length, borohydride concentration, and $\mathrm{HCl}$ concentration were varied until the maximum sensitivity for DMA and MMA were achieved. The reaction coil length was varied from 1-2 m, and the $\mathrm{NaBH}_{4}$ concentration was varied from $0.5 \%-1.5 \%(\mathrm{w} / \mathrm{v})$. The $\mathrm{HCl}$ concentration was varied from $5-25 \%(\mathrm{v} / \mathrm{v})$.

The extractability of MMA from SRM 2704, SRM 1944 and SRM 2710 was considered to be similar to the extractability of spiked DMA from SRM 2704. It is known that the humic matter, iron and other mineral contents all affect the degree of adsorption. The content of the SRM with respect to major and minor element composition is given in Table 4 from which it can be seen that the materials all have rather similar compositions. The natural deposition of MMA onto a sediment particle would be similar to the spiked deposition of the DMA. If the arsenic methylation was the result of microbial action, alkyl arsenic species are probably on the surfaces of sediment and soil particles, having been released in some way (excreted, expired, or secreted) by the microorganisms following transformation. It was also assumed, based on other work in our laboratory, ${ }^{82}$ that conditions which would extract DMA would also extract MMA.

Multi-cycle univariate optimization of the mass spectrometer operating parameters (torch position, purge gas flow, and ion lens voltage settings) was performed daily as described by Greenfield, et al. ${ }^{83}$ while a continuous stream of As(III) was introduced into the hydride generation manifold.

\section{Calibration}

Quantification of MMA in SRM 2704 was by external calibration and by internal standardization. The extraction efficiency used was assumed to be $100 \%$, based on the calculated efficiency in the DMA recovery studies. The external calibration was performed by injecting a series of 5 standard solutions of MMA. These standard solutions were matrix matched with respect to acid and acetone content. A plot of peak area $v s$. concentration was constructed and the concentration of unknowns was calculated on the basis of rectilinear least squares regression.

As SRM 2704 did not contain a measurable amount of DMA, the concentration of MMA could be additionally quantified by a procedure in which DMA was used as an internal standard. A known volume of a known concentration of DMA solution was added to the extract following centrifugation. First, the response factors for DMA and MMA were calculated from the peak areas of the two compounds obtained from a $20 \mu \mathrm{l}$ injection of a

Table 4 Elemental compositions (percent) of soils and sediment SRM

\begin{tabular}{lccc}
\hline Element & SRM 2704 & SRM 1944 & SRM 2710 \\
\hline Aluminium & 6.11 & 5.33 & 6.44 \\
Silicon & 29.08 & 31 & 28.97 \\
Iron & 4.11 & 3.53 & 3.38 \\
Manganese & 0.555 & 0.505 & 1.01 \\
Magnesium & 1.2 & $1.0^{a}$ & 0.853 \\
Sodium & 0.457 & 1.9 & 1.14 \\
Potassium & 2.00 & 1.6 & 2.11 \\
Carbon & 3.348 & $-b$ & $3^{a}$
\end{tabular}

${ }^{a}$ Indicates material is not certified for this element. ${ }^{b}$-Value not available. 
solution containing a known concentration of both species. These values were obtained before and after each analysis and the average ratio used in the calculation of the MMA concentration. The volume of the extractant was determined by subtraction of the mass of the centrifuge tube and dry sample from the total mass of the tube and contents after centrifugation, followed by division by the density of the extractant solution (0.90 $\left.\mathrm{mg} \mathrm{ml}^{-1}\right)$.

For SRM 2704 and 1944, four samples were taken, and for SRM 2710, three samples. Each sample was run twice and an average was taken.

\section{Results and discussion}

The parameters found to be the most important in maximizing the efficiency of the volatile hydride form of methylated arsenic species were the reaction coil length and the $\mathrm{NaBH}_{4}$ concentration; the acid concentration had no significant effect on sensitivity and a value of $25 \%$ was used. The signals for the two methylated arsenic species showed almost identical variation with operating parameters. At borohydride concentrations above $1.5 \%$, the hydrogen liberated from the $\mathrm{NaBH}_{4}-\mathrm{HCl}$ reaction extinguished the plasma. Although at reaction coil lengths greater than $2 \mathrm{~m}$ improved hydride generation efficiency was found, the peak broadening was too great to resolve DMA from As(III), an especially prevalent problem as the column aged and lost efficiency. Since the decrease in sensitivity for $01.5 \mathrm{~m}$ reaction coil was quite modest, this was selected for the reaction coil. The optimized conditions produced signals from the methylated species which were about $15 \%$ of that obtained for the same concentration of As(III).

The peak area response was linear up to $500 \mathrm{ng} \mathrm{ml}-1\left(R^{2}=\right.$ $0.9999)$ for both species. The $3 s$ peak area detection limit was $1 \mathrm{ng} \mathrm{ml}^{-1}$ for MMA (approximately $10 \mathrm{ng} \mathrm{g}^{-1}$ in the solid) and $2 \mathrm{ng} \mathrm{ml}^{-1}$ for DMA (approximately $20 \mathrm{ng} \mathrm{g}^{-1}$ in the solid).

\section{Extraction efficiency}

The recoveries of DMA spiked into Buffalo River sediment are shown in Table 5 for various solvents. There was no evidence of DMA degradation for those solvent combinations which included $\mathrm{HCl}$. These results together with the arsenic-specific chromatograms provide some insights into the extraction mechanisms. The presence of an organic modifier may aid in the solvent's ability to permeate (i.e. wet) the organic material in the soil, where the arsenic species could be adsorbed. Hydro- chloric acid is able to protonate most solvents in which it resides as well as producing hydronium ions. These cationic species could help in solubilizing anionic arsenic species by ionpairing. Simultaneously, chloride can serve as a strong electrolyte replacing anionic species retained at ion-exchange sites. The role of $\mathrm{Cl}^{-}$in an ion-exchange process could partially account for the improvement in extraction efficiency compared to those of earlier investigations. ${ }^{78}$ Additionally, there was little oxidative potential to any of the extraction solutions, so conversion of the arsenic species to inorganic As(v) was unlikely.

A significant amount of chromatographically unretained arsenic was observed in each of the extracts. It is noted that this unretained peak contains inorganic As(III), but also probably contains all other neutral or cationic arsenic species. Further separation of the co-eluting species was not attempted, and so the ability of different solvent systems to extract varying amounts of these arsenic species could not be evaluated. Varying the organic modifier hydrophobicity changes the speciation profile. It was noted that the more polar acetone- $\mathrm{HCl}$ and methanol- $\mathrm{HCl}$ systems removed comparatively more arsenate than did the isopropyl alcohol- $\mathrm{HCl}$ system, with less unretained arsenic compounds. The polarity of the modifier affects the solvent's ability to permeate the organic material of the soil, where the neutral arsenic species reside. A less polar solvent system would have poorer solvating ability for anions such as MMA and inorganic arsenate, and would be less efficient at removing them.

Near $100 \%$ recovery of spiked DMA was obtained with all three solvent systems. The aqueous acetone- $\mathrm{HCl}$ solvent system was chosen for the extraction of MMA from the other reference materials.

\section{Determination of MMA}

Table 6 shows the concentrations of MMA in the SRM, together with the percentage of the total arsenic that the MMA species contributes to the certified value. These concentrations were determined by external calibration, and assumed $100 \%$ extraction efficiency. The determination of DMA in SRM 2704 by internal standardization gave a value $(0.40 \pm 0.10 \mathrm{ppm})$ in agreement with the concentration found by external standardization. The internal standard method could not be used for SRM 2710 and 1944 because either there was a measurable amount of DMA in the extract (for SRM 1944), or because the unretained arsenic peak masked the retention position of the DMA (for SRM 2710).

The percentage of arsenic as MMA was remarkably similar for each of the materials coming from anaerobic environments (SRM 2704 and 1944). Although the MMA concentration was

Table 5 Extraction efficiencies (represented as DMA recovery in SRM 2704)

\begin{tabular}{|c|c|c|c|}
\hline Extraction solvent & Method & $\begin{array}{l}\text { Extraction } \\
\text { efficiency }(\%)\end{array}$ & Std Dev $(\%)$ \\
\hline $50 \%$ Acetone $-50 \%$ methanol & $\begin{array}{l}\text { Microwave } \\
\text { sonication }\end{array}$ & $\begin{array}{r}20 \\
8\end{array}$ & $\begin{array}{c}15(n=3) \\
1.8(n=3)\end{array}$ \\
\hline Isopropanol & $\begin{array}{l}\text { Microwave } \\
\text { sonication }\end{array}$ & $\begin{array}{r}15 \\
9\end{array}$ & $\begin{array}{l}8.2(n=3) \\
3.6(n=3)\end{array}$ \\
\hline $5 \% \mathrm{HCl}-50 \%$ acetone $(\mathrm{v} / \mathrm{v})$ & $\begin{array}{l}\text { Microwave } \\
\text { sonication }\end{array}$ & $\begin{array}{l}106 \\
100\end{array}$ & $\begin{array}{l}6.2(n=3) \\
7.5(n=3)\end{array}$ \\
\hline $5 \% \mathrm{HCl}-50 \%$ methanol (v/v) & $\begin{array}{l}\text { Microwave } \\
\text { sonication }\end{array}$ & $\begin{array}{l}112 \\
124\end{array}$ & $\begin{array}{l}17(n=3) \\
16(n=3)\end{array}$ \\
\hline $5 \% \mathrm{HCl}-50 \%$ isopropanol(v/v) & $\begin{array}{l}\text { Microwave } \\
\text { sonication }\end{array}$ & $\begin{array}{c}91 \\
92\end{array}$ & $\begin{array}{l}5.3(n=2) \\
4.5(n=3)\end{array}$ \\
\hline
\end{tabular}


Table 6 MMA concentrations (based on arsenic) in standard reference materials

\begin{tabular}{|c|c|c|c|}
\hline Material & $\begin{array}{l}\text { MMA concentration by ext. } \\
\text { calibration }(\mathrm{ppm})( \pm 95 \% \mathrm{CI})\end{array}$ & $\begin{array}{l}\text { Certified total } \\
\text { As conc. (ppm) }\end{array}$ & $\begin{array}{l}\text { MMA as a } \\
\text { percentage of total As }\end{array}$ \\
\hline $\begin{array}{l}\text { SRM } 2704 \\
\quad \text { (Buffalo River sediment) }\end{array}$ & $\begin{array}{c}0.30 \pm 0.13 \\
(n=4)\end{array}$ & 23.4 & $1.2 \%$ \\
\hline $\begin{array}{l}\text { SRM } 1944 \\
\quad \text { (NJ/NY waterway sediment) }\end{array}$ & $\begin{array}{c}0.23 \pm 0.12 \\
(n=4)\end{array}$ & 18.9 & $1.2 \%$ \\
\hline $\begin{array}{l}\text { SRM } 2710 \\
\quad \text { (Montana soil, highly } \\
\quad \text { elevated traces) }\end{array}$ & $\begin{array}{c}1.03 \pm 0.15 \\
\quad(n=3)\end{array}$ & 626 & $0.16 \%$ \\
\hline
\end{tabular}
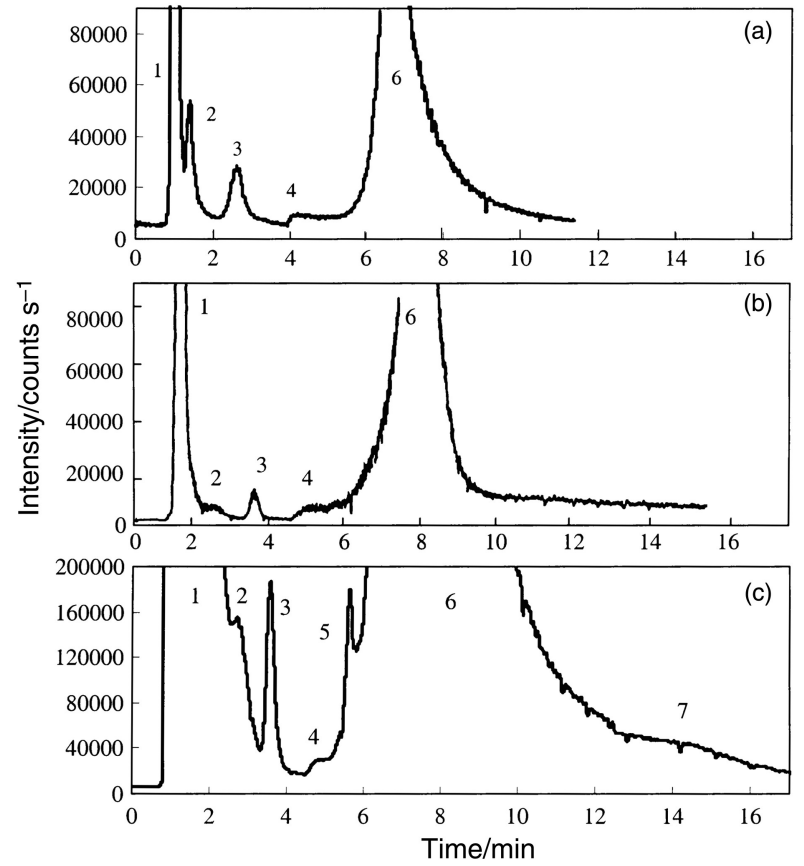

Fig. 2 Arsenic Speciation Profiles by HPLC-HG-ICP-MS. (a) SRM 2704 Buffalo River sediment; (b) SRM 1944 New York New Jersey waterway sediment; (c) SRM 2710 highly elevated Montana soil. 1. Unretained arsenic including $\mathrm{AsO}_{3}{ }^{2-}$; 2. DMA; 3. MMA; 4. Solvent impurity; 5. Unknown As species; 6. $\mathrm{AsO}_{4}{ }^{3-} ; 7$. Unknown As species. Column: PRPX100 anion-exchange column $(10 \mu \mathrm{m}$ particle size, $150 \mathrm{~mm} \times 4.1 \mathrm{~mm})$ Mobile phase: $10 \mathrm{mM}$ phosphate buffer, $\mathrm{pH}$ 6.0. Flow rate $2.0 \mathrm{ml} \mathrm{min} \mathrm{m}^{-1}$. Injection volume $20 \mu 1$.

highest in SRM 2710, the percentage of the total arsenic as MMA was about an order of magnitude lower than that for the reference materials taken from the anaerobic environments. While this could indicate that arsenic methylation is favored in an anaerobic medium, as has been found by other investigators who have studied biological arsenic methylation, ${ }^{2-4}$ it is also possible that the mineral forms of arsenate in these media are more suitable for methylation.

\section{Arsenic chromatographic profiles}

The arsenic-specific chromatograms of the acetone- $\mathrm{HCl}$ solvent system microwave extracts of (a) Buffalo River sediment (SRM 2704), (b) New York-New Jersey waterway sediment (SRM 1944), and (c) highly elevated Montana Soil (SRM 2710), are shown in Fig. 2.
The identity of MMA in the microwave assisted and sonication sample extracts was verified by both matching retention times with those of the standards, and by adding an MMA spike to the sample and observing an increase in the size of the MMA peak. It is apparent from the arsenic profiles that there are differences in the retention times of different species between SRMs, most notably between SRM 2704 and the others. Retention time shifts like this have been observed by previous investigators, and could be due to the presence of other anions in the extract. ${ }^{84}$ It was also observed that slight variations in mobile phase $\mathrm{pH}$ had a significant effect on the retention and separation of the arsenicals. Additionally, retention capacity and efficiency of the column changed over the course of the study.

The most stable form of terrestrial arsenic is inorganic As(v) as $\mathrm{AsO}_{4}{ }^{3-}$. Though it was not quantified in this investigation, this was the dominant form of extractable arsenic in all of the SRM investigated. There was evidence of a small amount of DMA in both the New York Harbor sediment (SRM 1944) and the Montana soil (SRM 2710), but the large peak for arsenic species eluting near the solvent front was not completely separated from the DMA peak. Future work to separate these unretained arsenic compounds (by reversed-phase or elementspecific gas chromatography) is a possible extension to this study. There were a considerably greater number of separable arsenic species detected in the Montana soil extracts than in either of the sediment extracts. Of the three materials, only the soil was taken from an aerobic environment. Alternatively, these compounds could be related to an arsenic-bearing mineral.

The relatively small amounts of the methylated forms of arsenic suggest that for the materials investigated, there was no mechanism for the accumulation of these methylated species. Thus if microbial action was responsible for the conversion of inorganic arsenic to methylated arsenic either (a) MMA and DMA are more water soluble than arsenate or (b) MMA and DMA are intermediates in a pathway that produces volatile trimethylarsine or trimethylarsine oxide. Alternative biological pathways such as the production of arsenobetaine may be part of a closed cycle as it has been shown, for example, that in active anaerobic marine cultures, arsenobetaine degrades into a number of less substituted arsenic compounds including $\mathrm{AsO}_{4}{ }^{3-} .{ }^{85}$ So far, little work has been done on the production and fate of methylated arsenicals in an aerobic environment.

\section{Conclusions}

Microwave-assisted extraction is a rapid, precise and quantitative procedure for extracting MMA from NIST soil and sediment reference materials. The dominant arsenic species in all extracts was inorganic $\mathrm{AsO}_{4}{ }^{3-}$. This species is the most 
stable from a redox perspective, and is a likely candidate as a stable end-product of degradation. Quantifiable amounts of MMA were found in NIST SRM 2704, SRM 1944, and SRM 2710. The sediment reference materials, taken from environments that were predominantly anaerobic, had proportionally more arsenic as MMA than did the soil reference material, taken from an environment that was predominantly aerobic.

\section{Acknowledgements}

The authors thank PerkinElmer Instruments for the provision of the inductively coupled plasma mass spectrometer and Questron Corporation for provision of the microwave extraction unit and control software. We also thank the National Institute of Standards and Technology for the gift of the standard reference materials used in this study. Peter Yehl thanks the University of Massachusetts, Amherst, for a Graduate School Fellowship.

\section{References}

1 F. Challenger, C. Higginbottom and L. Ellis, J. Chem. Soc., 1933, 95

2 B. C. McBride and R. S. Wolfe, Biochemistry, 1971, 10, 4312.

3 M. D. Baker, W. E. Innis, C. I. Mayfield, P. T. S. Wong and Y. K. Chau, Environ. Technol. Lett., 1983, 4, 89

4 W. R. Cullen and K. J. Reimer, Chem. Rev., 1989, 89, 713.

5 H. Gurleyuk, V. Van Fleet-Stadler and T. G. Chasteen, Appl. Organomet. Chem., 1997, 11, 471.

6 F. Challenger and H. E. North, J. Chem. Soc., 1934, 68

7 H. E. Guard, A. B. Cobet and W. M. Coleman, Science, 1981, 213 770 .

8 M. L. Bird and K. Challenger, J. Chem. Soc., 1939, 163.

9 U. Schmidt and F. Huber, Nature, (London), 1976, 259, 157.

10 P. T. S. Wong, Y. K. Chau and P. K. Luxon, Nature, (London), 1975 , 253, 263.

11 M. Hiroki and Y. Yoshiwarn, Soil Sci. Plant Nutr., 1993, 39, 243.

12 D. A. Bright, S. Brock, W. R. Cullen, G. M. Hewitt, J. Jafaar and K. J. Reimer, Appl. Organomet. Chem., 1994, 8, 415.

13 E. H. Larsen, M. Hansen and W. Gossler, Appl. Organomet. Chem., 1998, 12, 285

14 M. Dannan, S. Dally and F. Conso, Neurology, 1984, 34, 1524.

15 M. Vahter and E. Marafante, Chem. Biol. Interact., 1983, 47, 29.

16 M. Tezuka, K. Hanoika, K. Yamanaka and S. Okada, Biochem Biophys. Res. Commun., 1993, 191, 1178.

17 J. R. Cannon, J. B. Saunders and R. F. Toia, Sci. Total Environ., 1985, 31, 181 .

18 G. B. Freeman, R. A. Schoof, M. V. Ruby, A. O. Davis, S. C. Liao, C. A. Lapin and P. D. Bergstrom, Fundam. Appl. Toxicol., 1995, 28 215.

19 R. Bornschein, An Assessment of Residential Arsenic Exposure Among Children Living in the Vicinity of a Former Copper Smelter Plant. Prepared for Atlantic Richfield Company, Denver, CO. University of Cincinnati, 1994.

20 S. Tamaki and J. R. Frankenberger, Rev. Environ. Contam. Toxicol., 1992, 124, 79.

21 X. C. Le, W. R. Cullen and K. J. Reimer, Talanta, 1994, 41, 495

22 E. H. Larsen and S. H. Hansen, Mikrochim. Acta, 1992, 109, 47.

23 L. Ebdon, Anal. Chim. Acta, 1982, 136, 191.

24 T. Shepard and J. Caruso, Analyst, 1992, 117, 971.

25 L. Ebdon and S. Hill, Anal. Proc., 1986, 23, 6.

26 K. Hanaoka, H. Yamamota, K. Kawashima, S. Tagawa and T. Kaise, Appl. Organomet. Chem., 1988, 2, 371.

27 W. R. Cullen and M. Dodd, Appl. Organomet. Chem., 1989, 3, 401.

28 D. Beauchemin, J. Anal. At. Spectrom., 1998, 13, 1.

29 M. Moldovan, M. M. Gomez, M. A. Palacios and C. Camara, Microchem. J., 1998, 59, 89.

30 S. H. Hansen, E. Larsen, G. Pritzl and C. Cornett, J. Anal. At. Spectrom., 1992, 7, 629.
31 R. Indevia, N. Aharonson and E. A. Woolson, J. Assoc. Off. Anal. Chem., 1980, 63, 742.

32 M. S. Mohan, R. A. Zingara, P. Micks and P. O. Clark, Int. J. Environ Anal. Chem., 1982, 11, 175.

33 B. A. Manning and D. A. Martens, Environ. Sci. Technol., 1997, 31 171.

34 D. L. Tsalev, M. Sperling and B. Welz, Analyst, 1998, 123, 1703.

35 M. B. Amran, F. Lagarde and M. J. F. Leroy, Mikrochim. Acta, 1997 127, 195.

36 B. P. Jackson and W. P. Miller, Environ. Sci. Technol., 1999, 15, 270.

37 X. C. Le, W. R. Cullen and K. J. Reimer, Clin. Chem., 1994, 40, 617.

38 R. Rubio, A. P. Alberti and G. Rauret, Mikrochim. Acta, 1992, 109, 39.

39 A. G. Howard and S. D. W. Comber, Mikrochim. Acta, 1992, 109 27

40 L. Ebdon, S. Hill, A. P. Walton and R. W. Ward, Analyst, 1988, 113 1159.

41 K. B. Olsen, D. S. Sklarew and J. C. Evans, Spectrochim. Acta, Part $B, 1985,40,357$.

42 Y. Shibata and M. Morita, Appl. Organomet. Chem., 1992, 6, 343.

43 S. Maeda, A. K. Ohki, K. K. Miyahara, K. Naka and S. Higashi, Appl. Organomet. Chem., 1992, 6, 415.

44 K. Hanaoka, S. Tagawa and T. Kaise, Appl. Organomet. Chem., 1991, 5, 435 .

45 K. Shiomi, Y. Horiguchi and T. Kaise, Appl. Organomet. Chem., 1988, 2, 385

46 T. Kaise and F. Shozo, Appl. Organomet. Chem., 1992, 6, 155

47 K. L. Ackley, C. B'Hymer, K. L. Sutton and J. A. Caruso, J. Anal. At Spectrom., 1999, 14, 845

48 K. Jin, T. Hayashi, Y. Shibata and M. Morita, Appl. Organomet Chem., 1988, 2, 365 .

49 T. Tusuda, H. Nakanisi, S. Aoki and J. Takebayashi, J. Chromatogr., 1987, 387, 361.

50 K. J. Lamble and S. J. Hill, Anal. Chim. Acta, 1996, 334, 261.

51 T. Dagnac, A. Padro, R. Rubio and G. Rauret, Anal. Chim. Acta, 1998, 364, 19

52 J. W. McKiernan, J. T. Creed, C. A. Brockhoff, J. A. Caruso and R. M. Lorenzana, J. Anal. At. Spectrom., 1999, 14, 607.

53 M. Stoeppler, M. Burow, K. May, S. Padberg and G. Kloster, Mikrochim. Acta, 1992, 109, 107.

54 T. Kaise and F. Shozo, Appl. Organomet. Chem., 1992, 6, 155.

55 R. M. Harrison and S. Rapsomanikis, Environmental Analysis Using Chromatography Interfaced with Atomic Spectroscopy, Ellis Horwood, Chichester, 1989.

56 J. Chappell, B. Chiswell and H. Olszowy, Talanta, 1995, 42, 323.

57 P. Thomas, J. K. Finnie and J. G. Williams, J. Anal. At. Spectrom. 1997, 12, 1367.

58 M. Burguera and J. L. Burguera, Talanta, 1997, 44, 1581.

59 D. Velez, N. Ybanez and R. Montoro, J. Anal. At. Spectrom., 1996, 11, 271.

60 M. D. Mueller, Fresenius' Z. Anal. Chem., 1984, 317, 32.

61 K. S. Epler, T. C. O'Haver, G. C. Turk and W. A. MacCrehan, Anal Chem., 1988, 60, 2062

62 T. Tsuda, H. Nakanishi, T. Morita and J. Takebayashi, Assoc. Off. Anal. Chem., 1986, 69, 981.

63 M. Lee and C. E. Makides, Analytical Supercritical Fluid Chromatography and Extraction, Chromatography Conferences, Provo, UT, 1990.

64 C. Berger and M. Perrut, J. Chromatogr., 1990, 28, 468.

65 B. A. Charpentier and M. R. Senenats, Supercritical Fluid Extraction and Chromatography, ACS Symposium Series, Washington, 1988.

66 Y. Liu, V. Lopez-Avila and M. Alcaraz, J. High Resolut. Chroma togr., 1993, 16, 106

67 A. Tessier, P. G. C. Campbell and M. Bisson, Anal. Chem., 1979, 51 844.

68 R. F. Sanzalone and T. T. Chao, Soil Sci. Soc. Am. J., 1989, 53 385 .

69 S. Xiao-Quan and B. Chen, Anal. Chem., 1993, 65, 802.

70 I. Novozamsky, T. M. Lexmond and V. J. G. Houba, Int. J. Environ. Anal. Chem., 1993, 51, 47.

71 P. Del Castilho and I. Rix, Int. J. Environ. Anal. Chem., 1993, 51, 59

72 D. E. Wells, Mikrochim. Acta, 1992, 109, 13

73 L. Orsini and A. Bermond, Int. J. Environ. Anal. Chem., 1993, 51, 97

74 P. E. Gardiner, Fresenius' J. Anal. Chem., 1993, 345, 287.

75 V. Lopez-Avila, R. Young and W. Beckert, Anal. Chem., 1994, 66, 1097. 
76 F. I. Onuska and K. A. Terry, Chromatographia, 1993, 36, 191.

77 H. De Geus, B. N. Zegers, H. Lingeman and U. A. Th. Brinkman, J. Environ. Anal. Chem., 1994, 56, 119.

78 G. Rauret, R. Rubio and A. Padro, Fresenius' J. Anal. Chem., 1991, 340, 157.

79 E. H. Larsen and S. H. Hansen, Mikrochim. Acta, 1992, 109, 47.

80 D. Velez, N. Ybanez and R. Montoro, J. Anal. At. Spectrom., 1996, 11, 271.
81 P. M. Yehl and J. F. Tyson, Anal. Commun., 1997, 34, 49.

82 H. Gurleyuk, PhD Thesis, University of Massachusetts, 2001.

83 S. Greenfield, M. S. Salman, M. Thomsen and J. F. Tyson, J. Anal. At. Spectrom., 1989, 4, 55.

84 A. M. Debettencourt, M. H. Florencio, M. F. N. Duarte, M. L. R. Gores and L. F. C. V. Boas, Appl. Organomet. Chem., 1994, 8, 43.

85 S. Maeda, K. Kusadome, H. Arima, A. Ohki and K. Naka, Appl. Organomet. Chem., 1992, 6, 407. 